\title{
Relationship between erb-B2 mRNA Expression in Blood and Tissue of Invasive Ductal Carcinoma Breast Cancer Patients and Clinicopathological Characteristics of the Tumors
}

\author{
Neda Moazzezy ${ }^{1}$, Fatemeh Ebrahimi ${ }^{1}$, Mahsa Mollapour Sisakht ${ }^{1}$, Hossein \\ Yahyazadeh $^{2}$, Saeid Bouzari ${ }^{1}$, Mana Oloomi ${ }^{1 *}$
}

\begin{abstract}
Molecular detection methods such as RT-PCR for detecting breast cancer-associated gene expression in the peripheral blood have the potential to modify breast cancer $(\mathrm{BC})$ staging and therapy. In this regard, we evaluated the potential of erb-B2 molecular marker in BC detection and analyzed the expression of erb-B2 mRNA in the peripheral blood and fresh tissue samples of 50 pretreated female $\mathrm{BC}$ patients and 50 healthy females by reverse transcription-PCR (RT-PCR) method. We also assessed the correlation of erb-B2 mRNA marker positivity in peripheral blood and tumor tissue samples with clinical and pathological factors in BC patients in order to evaluate its prognostic value. It was shown that there is a significant difference between healthy females and BC patients with expression of the erb-B2 molecular marker $(\mathbf{p}<0.01)$. A significant difference between the expression of erb-B2 in the peripheral blood and tissue samples of $\mathrm{BC}$ patients $(\mathrm{p}<0.01)$ and the frequency of circulating erb-B2 mRNA expression in peripheral blood and in tissue was detected by RT-PCR. No correlation was found between erb-B2 mRNA expression in blood or tumor tissue samples and lymph node, tumor grade, tumor stage, tumor size, patient's age, ki67, estrogen receptor (ER), progesterone receptor (PGR), P53, and HER-2 status. However, in a small subset of $31 \mathrm{BC}$ patients we found that expression of erb-B2 in peripheral blood or in both peripheral blood and tumor tissue was directly correlated with lympho-vascular invasion and perineural invasion as poor prognostic features. The highest rates of erb-B2 expression in peripheral blood or tumor tissue were in the ER and PR negative and HER-2 positive group. This study suggests that the application of the RT-PCR and immunohistochemical methods for erb-B2 molecular marker detection would provide a higher detection rate, especially in early stage $\mathrm{BC}$.
\end{abstract}

Keywords: Breast cancer - reverse transcription - PCR (RT-PCR) - erb-B2 - marker

Asian Pac J Cancer Prev, 17 (1), 249-254

\section{Introduction}

One of the most common cancers among Iranian women that can be caused mortality is breast cancer (BC) and the incidence of this dilemma is currently increasing (Taghavi et al., 2012). The remarkable thing is that BC can be treated more easily and effectively in early stages. Therefore, early detection of $\mathrm{BC}$ as one of the most promising way can reduce mortality from this health problem (Dey, 2014). Detection of circulating tumor cells in peripheral blood is considered as useful tools for early diagnosis and may finally improve the early detection rate of BC patients (Ross et al., 2009). Molecular biology based techniques such as reverse transcriptase-polymerase chain reaction (RT-PCR) can be used for cancer specific gene transcripts (tumor cell markers) in the blood that are sensitive and specific for the detection of BC (Gilbey et al., 2004).
Human epidermal growth factor receptor- 2 or HER2 (also called c-erbB2) is a tissue biomarker that acts as a networking receptor and mediates signaling to cancer cells, causing them to proliferate (Wang et al., 2015). erb-B2 oncogene plays an important role in development and progression of $\mathrm{BC}$ and overexpression of that has been found in $30 \%$ of human BC (Xu et al., 2006). Reliable detection of erb-B2 overexpression (amplification of erb-B2 gene or overexpression of the protein) is important because of its role in therapeutic approach. In addition to early detection, research about tumor molecular profiles can be improved patient prognosis and care (Yan et al., 2015).

Because of the importance of erb-B2 in BC diagnosis and specially in clinical practice, in this study we compared the expression of erb-B2 in peripheral blood samples with the expression of that in fresh tissues, collected from patients with localized BC, by means of 
reverse transcriptase-polymerase chain reaction (RTPCR). In addition, the relationship between the expression of erb-B2 and clinicopathological characteristics was also investigated.

\section{Materials and Methods}

\section{Patients and healthy controls}

Fifty female recognized as BC patients without any neoadjuvant chemotherapy, before surgery who have presented to Milad hospital, Tehran, between May 2012 and March 2013, were included in this study. Clinical assessment was carried out based on histological reports at different stages. Breast cancer staging (I-IV) classified according to standard criteria based on data of TNM (Tumor, Nodes and Metastases) and American Joint Committee on cancer staging system (AJCC). The tumors were graded histologically according to the modified Bloom-Richardson grading system. Fifty age-matched healthy female volunteers with no history of breast cancer were taken as control. This study was approved by the ethical and scientific committee of Pasteur Institute of Iran and written consent form was signed by each subject for specimen collection.

\section{Biospecimen collection}

Peripheral blood samples were collected from patients prior to treatments and from healthy controls in buffered sodium citrate tube for RNA extraction. Fresh, diseased tissue is collected immediately after surgery and preserved in special fixative RNA later which preserves RNA. All were classified as invasive ductal carcinomas.

\section{RNA isolation}

AccuZol $^{\mathrm{TM}}$ (BIONEER) reagent was used for the isolation of total RNA from tumor tissues and blood specimens. In brief, $750 \mu \mathrm{l}$ AccuZol was added into 250 $\mu 1$ blood sample or 50-100mg of tissue were used for sample lysis and for denaturation. It was incubated for 5 min at room temperature, then added $200 \mu 1$ chloroform to the tube. After centrifugation at $4^{\circ} \mathrm{C}$, the supernatants containing the intact RNA was transferred to a new tube, then precipitating RNA with equal volume of isopropyl alcohol, and washing with $80 \%$ ethanol, the RNA was solubilized in RNase free water. Nanodrop spectrophotometry and Agarose gel staining with ethidium bromide used to assess RNA quantity and integrity, respectively. After ensuring quality of purified RNA, it was used for gene expression.

\section{Reverse Transcriptase-Polymerase Chain Reactions (RT-PCR)}

Total extracted RNA was amplified by one step AccuPower ${ }^{\circledR}$ RT-PCR Premix (BioNEER) Kit. All components necessary for cDNA synthesis and amplification were provided in one tube. The sequences of primers used for Glyceraldehyde 3-phosphate dehydrogenase (GAPDH) detection in this study are 5'-GGTCGGAGTCAACGGATTTG-3' as a Forward primer and for Reverse primer 5 ' - ATGAGCCCCAGCCT TCTCCAT-3' was used. For erb-B2 cDNA Forward primer 5'-CTGGTGACACAGCTTATGCCCT-3' and Reverse primer 5'-ATCCCCTTGGCAATCTGCA-3' were used. Specific primers were used for erb-B2 in our study (Oloomi et al., 2013). The RT-PCR product for GAPDH and erb-B2 was 319 and 113 base pair (bp), respectively.

The quality of RNA isolates was verified by the amplification of the housekeeping gene GAPDH. Presence of GAPDH mRNA was taken as an internal control (31.2pg). The purpose of using GAPDH internal control gene is to normalize the PCRs for the amount of RNA added to the reverse transcription reactions. In this experiment, extracted RNA $(1 \mu \mathrm{g})$ was used with the same amount of GAPDH RT-PCR product in order to obtain the same sensitivity for erb-B2 gene expression. The extracted RNA and the reverse primer were mixed and incubated at $70^{\circ} \mathrm{C}$ for $5 \mathrm{~min}$. The incubated mixture and the forward primer were then transferred to a premix tube. The cDNA synthesis was performed at $42^{\circ} \mathrm{C}$ for 60 min and at $94^{\circ} \mathrm{C}$ for $5 \mathrm{~min} .30$ cycles of PCR was found optimal. PCR cycles were carried out as follows: $94^{\circ} \mathrm{C}$ for $60 \mathrm{sec}, 54^{\circ} \mathrm{C}$ for $30 \mathrm{sec}$ and $72^{\circ} \mathrm{C}$ for $60 \mathrm{sec}$ with a final $10 \mathrm{~min}$ extension at $72^{\circ} \mathrm{C}$. Negative control represented by all RT-PCR reagents without mRNA was run in each experiment. The aliquots of PCR products were visualized by electrophoresis on $2 \%$ agarose gel containing ethidium bromide under UV absorbance.

\section{Cell line}

SK-BR-3 human BC cell line, which expresses erb-B2, was used as positive control to help ensure suitable assay performance. It was purchased from (National Cell Bank, Pasteur Institute of Iran) and cultured in RPMI-1640 medium (Biosera) supplemented with penicillin (100U/ $\mathrm{ml})$, streptomycin $(100 \mu \mathrm{g} / \mathrm{ml})$, and $10 \%$ fetal bovine serum. Cells were grown and maintained at $37^{\circ} \mathrm{C}$ in $5 \%$ $\mathrm{CO}_{2}$ in a humidified incubator.

\section{Statistical analysis}

Student's t-test and Pearson's chi-square $\left(\mathrm{x}^{2}\right)$ test was performed to evaluate correlation between erb-B2 mRNA detection in the peripheral blood and tumor tissue samples. The age, tumor size, lymph node status, histological grade, stages, lymphovascular invasion, perineural invasion and tissue marker status were also considered. A value of $\mathrm{P}<0.05$ was considered statistically significant. Data processing was performed using SPSS software version 18.

\section{Results}

Clinical, Pathological, and Immunohistochemical results

A total of 50 female BC patients with a mean age of $48.40 \pm 1.43$ years (range: 23 to 70 years) were considered in this study. $22 \%(\mathrm{n}=11)$ and $52 \%(\mathrm{n}=26)$ of these patients were under 40 and 50 years, respectively. Histologic tumor type of all BC patients was invasive ductal carcinoma and among them, $32 \%(n=16)$ was diagnosed as nose type. According to tumor size $(\mathrm{T}), 12 \%(\mathrm{n}=6)$ of patients were T1 (Tumor with diameters $\leq 2 \mathrm{~cm}), 70 \%(\mathrm{n}=35)$ of patients were T2 (Tumor with diameters $>2 \mathrm{~cm}$ ) and 
erb-B2 mRNA Expression in Blood and Tissue and Clinicopathological Characteristics of Invasive Ductal Breast Cancer

$18 \%(\mathrm{n}=9)$ of patients were T3 (Tumor with diameters $\geq 5 \mathrm{~cm}$ ). Regarding lymph node status, patients with negative lymph node was $52 \%(\mathrm{n}=26)$ and patients with positive lymph node was $46 \%(n=23)$. According to the

Table 1. Clinical-Pathological Characteristics

\begin{tabular}{|c|c|c|}
\hline Characteristic & $\mathrm{N}$ & $\%$ \\
\hline patients & 50 & 100 \\
\hline \multicolumn{3}{|l|}{ Mean age $48.40 \pm 1.43=(23-70$ range $)$} \\
\hline$<50$ years & 26 & 52 \\
\hline$\geq 50$ years & 24 & 48 \\
\hline \multicolumn{3}{|l|}{ Histological subtype } \\
\hline Invasive ductal carcinoma(IDC) & 34 & 68 \\
\hline Invasive ductal carcinoma nose type (IDC(NOS)) & 16 & 32 \\
\hline \multicolumn{3}{|l|}{ Tumor size $(\mathrm{cm})$} \\
\hline $\mathrm{T} 1 \leq 2$ & 6 & 12 \\
\hline $5>\mathrm{T} 2>2$ & 35 & 70 \\
\hline $\mathrm{T} 3 \geq 5$ & 9 & 18 \\
\hline \multicolumn{3}{|l|}{ Lymph node status } \\
\hline Negative & 26 & 52 \\
\hline Positive & 23 & 46 \\
\hline Unknown & 1 & 2 \\
\hline \multicolumn{3}{|l|}{ Histopathologic grade } \\
\hline G I & 6 & 12 \\
\hline G II & 29 & 58 \\
\hline G III & 15 & 30 \\
\hline \multicolumn{3}{|l|}{ Stages } \\
\hline $\mathrm{I}$ & 3 & 6 \\
\hline II & 36 & 72 \\
\hline III & 8 & 16 \\
\hline IV & 2 & 4 \\
\hline Unknown & 1 & 2 \\
\hline \multicolumn{3}{|l|}{ Lymphovascular Invasion(LVI) } \\
\hline Negative & 17 & 34 \\
\hline Positive & 14 & 28 \\
\hline Unknown & 19 & 38 \\
\hline \multicolumn{3}{|l|}{ Perineural Invasion (PNI) } \\
\hline Negative & 16 & 32 \\
\hline Positive & 15 & 30 \\
\hline Unknown & 19 & 38 \\
\hline \multicolumn{3}{|l|}{ Tissue marker status } \\
\hline $\mathrm{Ki} 67+$ & 47 & 94 \\
\hline $\mathrm{ER}+$ & 38 & 76 \\
\hline $\mathrm{PR}+$ & 36 & 72 \\
\hline $\mathrm{P} 53+$ & 15 & 30 \\
\hline HER-2 + & 18 & 36 \\
\hline Unknown & 1 & 2 \\
\hline \multicolumn{3}{|l|}{ Immunohistochemical profile } \\
\hline Group A(HR positive and HER-2 negative) & 27 & 54 \\
\hline Group B (HR positive and HER-2 positive) & 11 & 22 \\
\hline Group C(HR negative and HER-2 positive) & 7 & 14 \\
\hline Group D (HR negative and HER-2 negative) & 5 & 10 \\
\hline
\end{tabular}

$\mathrm{N}$ : number of subjects/ ER: estrogen receptor/ PR: progesterone receptor/ HER-2: human epidermal growth factor receptor 2/HR: ER, PR
Bloom-Richardson grading system $12 \%(n=6)$ of tumors were well differentiated (grade 1), $58 \%(n=29)$ of tumors were moderately differentiated (grade II) and 30\% ( $\mathrm{n}=15)$ of tumors were poorly differentiated (grade III). In this study, patients were mainly in the early stage of breast cancer 6\% $(n=3)$ in Stage I, 72\% $(n=36)$ in Stage II, 16\% $(n=8)$ in Stage III and $4 \%(n=2)$ in stage IV. 31 patients with lympho-vascular and perineural invasion was known. Patients with negative lymphovascular invasion (LVI) and negative perineural invasion (PNI) was $34 \%(n=17)$ and $32 \%(n=16)$, respectively and patients with positive lymphovascular invasion and positive perineural invasion was $28 \%(n=14)$ and $30 \%(n=15)$, respectively. Finally, based on tissue marker status, 94\% $(n=47)$ were Ki-67 positive, $76 \%(n=38)$ were ER positive, $72 \%(n=36)$ were PR positive, $30 \%(n=15)$ were P53 positive and $36 \%$ $(n=18)$ were Her2 positive, as shown in Table 1.

Table 2. Distribution of mRNA Markers erb-B2 Detection in Controls and Patients

\begin{tabular}{lrr}
\hline mRNA gene expression & $\mathrm{N}$ & $\%$ \\
\hline Healthy female & & \\
$\quad$ erb-B2 B(+) & 6 & 12 \\
patients & 22 & 44 \\
erb-B2 B (+) & 3 & 6 \\
erb-B2 B (+)\&T(-) & 40 & 80 \\
erb-B2 T(+) & 21 & 42 \\
erb-B2 B(-)\&T(+) & 19 & 38 \\
erb-B2 B\&T(+) & 7 & 14 \\
erb-B2 B\&T(-) & 43 & 86 \\
erb-B2B /\&or T(+) &
\end{tabular}

T: Tumor; B: Blood; erb-B2 (+) B: marker positive in blood; erb-B2 (+) T: marker positive in tumor; erb-B2 (-)B: marker negative in blood; erb-B2 (-) T: marker negative in tumor;erb-B2 (+)B \&erb-B2 (+) T: marker positive in blood and tumor;erb-B2 (+)B or erb-B2 (+)T: marker in blood or tumor positive

Table 3. Measurement of Diagnostic Performance of erb-B2

\begin{tabular}{lc}
\hline & erb-B2 blood \\
\hline Sen $\%$ & $44.00 \%$ \\
Sen $(95 \% \mathrm{CI})$ & $29.99 \%$ to $58.75 \%$ \\
Spe $\%$ & $90.00 \%$ \\
Spe $(95 \% \mathrm{CI})$ & $79.49 \%$ to $96.24 \%$ \\
PPV & $78.57 \%$ \\
PPV $(95 \% \mathrm{CI})$ & $59.05 \%$ to $91.70 \%$ \\
NPV & $65.85 \%$ \\
NPV $(95 \% \mathrm{CI})$ & $54.55 \%$ to $75.97 \%$
\end{tabular}

Sen: Sensitivity; Spe: Specificity; PPV: Positive predictive value; NPV: Negative predictive value; $95 \%$ CI: $95 \%$ confidence interval

Table 4. Correlation between Lymph Node, Grade, Stage, Tumor Size, Age, LVI, PNI Anderb-B2 mRNA Expression in Patients with Breast Cancer

\begin{tabular}{lcccccccc}
\hline mRNA gene expression & $\mathrm{P}^{1}$ & $\mathrm{P}^{2}$ & $\mathrm{P}^{3}$ & $\mathrm{P}^{4}$ & $\mathrm{P}^{5}$ & $\mathrm{P}^{6}$ & $\mathrm{P}^{7}$ & $\mathrm{P}^{8}$ \\
\hline erb-B2 T(+) & 0.13 & 0.12 & 0.08 & 0.57 & 0.23 & 0.56 & 0.36 & 0.42 \\
erb-B2 B(+) & 0.42 & 0.38 & 0.64 & 0.45 & 0.82 & 0.16 & 0.00 & 0.02 \\
erb-B2 B\&T(+) & 0.29 & 0.40 & 0.41 & 0.27 & 0.52 & 0.46 & 0.00 & 0.02 \\
erb-B2 B /\&or T(+) & 0.15 & 0.10 & 0.54 & 0.54 & 0.29 & 0.77 & 0.29 & 0.37 \\
\hline
\end{tabular}

P: P value; $\mathrm{P}^{1}$ : lymph node positive vs. negative; $\mathrm{P}^{2}$ : grade I, II vs. III; P3: grade I vs. II or grade I vs. III or grade II vs. III; P4: Stage I, II vs. III, IV/ $\mathrm{P}^{5}$; T1 vs. T2, T3; $\mathrm{P}^{6}$ : age $\leq 50 y$ ears vs. $>50$ years; $\mathrm{P}^{7}$ : LVI (Lymphovascular Invasion) positive vs. negative; $\mathrm{P}^{8}$ : PNI (Perineural Invasion) positive vs. negative 
Distribution of mRNA markers erb-B2 detection in controls and patients

Based on RT-PCR analysis, the percentage of erb-B2 transcript in the peripheral blood and tumor tissue samples for all BC patients and healthy controls were demonstrated in Table 2. $22(44 \%)$ and $40(80 \%)$ of patients were positive for erb-B2 transcript in peripheral blood and tumor tissue, respectively $(\mathrm{p}<0.01)$, while it was expressed only in $6(12 \%)$ peripheral blood of healthy controls $(\mathrm{p}<0.01)$. In $\mathrm{BC}$ patients, erb-B2 transcript was expressed $19(38 \%)$, in both peripheral blood and tumor tissue samples, while 7 (14\%) of BC patients was negative for erb-B2 expression in both peripheral blood and tumor tissue samples. $3(6 \%)$ of $\mathrm{BC}$ patients who had a positive erb-B2 mRNA in blood samples, were negative in the tumor tissue samples and $21(42 \%)$ of BC patients who had a positive erb-B2 mRNA in tumor tissue samples, were negative in the blood samples. Finally, 43 (86\%) of patients were positive for erb-B2 transcripts in peripheral blood or tumor tissue.

\section{Measurement of diagnostic performance of Erb-B2/neu}

Diagnostic performance of erb-B2 was presented in table 3. It was showed $44 \%(95 \% \mathrm{CI}=29.99 \%$ to $58.75 \%)$ sensitivity and $90 \%$ (95\% CI $=79.49 \%$ to $96.24 \%$ ) specificity. The false positive and negative rate for erb-B2 was $78.57 \%$ (95\% CI $=59.05 \%$ to $91.70 \%$ ) and $65.85 \%$ $(95 \% \mathrm{CI}=54.55 \%$ to $75.97 \%)$, respectively.

Correlation between clinicopathological factors and erb-B2 mRNA expression

Based on table 4, no correlation was found between erb-B2 mRNA expression in blood or tumor tissue samples and lymph node, tumor grade, tumor stage, tumor size, and patient's age. However, erb-B2 expression in peripheral blood or in both peripheral blood and tumor tissue showed statistically significant relations with the positivity of lympho vascular invasion and perineural invasion $(\mathrm{p}=0.00$,

Table 5. Correlation between Tissue Marker Status and erb-B2 mRNA Expression in Patients with Breast Cancer

\begin{tabular}{lccccc}
\hline mRNA gene expression & $\mathrm{P}^{1}$ & $\mathrm{P}^{2}$ & $\mathrm{P}^{3}$ & $\mathrm{P}^{4}$ & $\mathrm{P}^{5}$ \\
\hline erb-B2 T(+) & 0.67 & 0.24 & 0.15 & 0.09 & 0.52 \\
erb-B2 B(+) & 0.66 & 0.85 & 0.91 & 0.07 & 0.24 \\
erb-B2 B\&T(+) & 0.69 & 0.76 & 0.66 & 0.06 & 0.48 \\
erb-B2 B /\&or T(+) & 0.77 & 0.51 & 0.38 & 0.05 & 0.19 \\
\hline
\end{tabular}

$\mathrm{P}$ : $\mathrm{P}$ value; $\mathrm{P}^{1}$ : ki67positive vs. negative; $\mathrm{P}^{2}$ : ER positive vs. negative; $\mathrm{P}^{3}$ : $\mathrm{PR}$ positive vs. negative; $\mathrm{P}^{4}$ : $\mathrm{p} 53$ positive vs. negative; $\mathrm{P}^{5}$ : erb-B2 positive vs. negative

$\mathrm{p}=0.02$ ), respectively. The correlation between tissue marker status ki67, ER, PR, P53, Her2 and erb-B2 mRNA expression in peripheral blood or tumor tissue samples is shown in Table 5.

Expression of erb-B2 in different groups and comparison of erb-B2 positive rates between different groups

On the basis of the HR and HER-2 status, the 50 cases of invasive ductal BC patients were categorized into four groups (Table 1). Patients who were HR positive (ER and/or PR positive) and HER-2 negative were in Group A $(n=27)$. Patients who were HR positive and HER-2 positive were in Group B $(n=11)$. Patients who were HR negative (ER and PR negative) and HER-2 positive made up Group $C(n=7)$. Patients who were HR negative and HER-2 negative made up Group D $(n=5)$. Most of our patients were in group A and the least of them were in group D.

The expression of erb-B2 in tumor tissue, peripheral blood, in both tumor tissue and peripheral blood and in tumor tissue and/or peripheral blood samples was $74 \%$, $44 \%, 37 \%, 81 \%$, respectively in group A, $82 \%, 45 \%$, $36 \%, 91 \%$, respectively in group $\mathrm{B}, 100 \%, 57 \%, 57 \%$, $100 \%$, respectively in group $\mathrm{C}$ and $80 \%, 20 \%, 20 \%$, $80 \%$, respectively in group D (Table 6). Therefore, the expression of erb-B2 in tumor tissue, in peripheral blood, in both tumor tissue and peripheral blood and in tumor tissue and/or peripheral blood was higher in the HER-2 positive group (group C) than the other 3 groups.

There were significant differences of the erb-B2 expression in the peripheral blood, tumor tissue, peripheral blood and tumor tissue, peripheral blood and/or tumor tissue in group A versus B and A versus $C$ (all $\mathrm{p}<0.05$ ) (Table 7). There were also significant differences in erb-B2 expression in tumor tissue and peripheral blood and/or tumor tissue in group A versus $\mathrm{D}(\mathrm{p}<0.05)$. There were no significant comparisons in group $\mathrm{B}$ versus $\mathrm{C}$, B versus $\mathrm{D}$ and $\mathrm{C}$ versus $\mathrm{D}(\mathrm{P}>0.05)$.

Table 7. Comparison of erb-B2 Positive mRNA Expression between Groups

\begin{tabular}{lcccccc}
\hline mRNA gene expression & $\mathrm{P}^{1}$ & $\mathrm{P}^{2}$ & $\mathrm{P}^{3}$ & $\mathrm{P}^{4}$ & $\mathrm{P}^{5}$ & $\mathrm{P}^{6}$ \\
\hline erb-B2 $\mathrm{T}(+)$ & 0.00 & 0.00 & 0.03 & 0.11 & 0.26 & 0.33 \\
erb-B2 $\mathrm{B}(+)$ & 0.00 & 0.01 & 0.26 & 0.23 & 0.58 & 0.63 \\
erb-B2 B\&T(+) & 0.02 & 0.01 & 0.28 & 0.24 & 0.60 & 0.60 \\
erb-B2 B /\&or T(+) & 0.00 & 0.00 & 0.03 & 0.11 & 0.25 & 0.35 \\
\hline $\mathrm{P}^{1}$ : Group A vs. Group B; $\mathrm{P}^{2}$ : Group A vs. Group C; $\mathrm{P}^{3}$ : Group A vs. \\
Group D; $\mathrm{P}^{4}$ : Group B vs. Group C; $\mathrm{P}^{5}$ : Group B vs. Group D; $\mathrm{P}^{6}$ : Group \\
C vs. Group D
\end{tabular}

Table 6. Distribution of 50 Invasive Ductal Breast Cancer patients in four Groups

\begin{tabular}{|c|c|c|c|c|c|c|c|c|}
\hline \multirow{3}{*}{$\begin{array}{l}\text { mRNA gene expression } \\
\text { erb-B2 } \mathrm{T}(+)\end{array}$} & \multicolumn{2}{|c|}{$\begin{array}{c}\text { Group A } \\
\text { (HR positive and } \\
\text { Her2 negative) }\end{array}$} & \multicolumn{2}{|c|}{$\begin{array}{c}\text { Group B } \\
\text { (HR positive and } \\
\text { Her2 positive) }\end{array}$} & \multicolumn{2}{|c|}{$\begin{array}{c}\text { Group C } \\
\text { (HR negative and } \\
\text { Her2 positive) }\end{array}$} & \multicolumn{2}{|c|}{$\begin{array}{c}\text { Group D } \\
\text { (HR negative and } \\
\text { Her2 negative) }\end{array}$} \\
\hline & $(\mathrm{N}=27)$ & $\%$ & $(\mathrm{~N}=11)$ & $\%$ & $(\mathrm{~N}=7)$ & $\%$ & $(\mathrm{~N}=5)$ & $\%$ \\
\hline & 20 & 74 & 9 & 82 & 7 & 100 & 4 & 80 \\
\hline erb-B2 B(+) & 12 & 44 & 5 & 45 & 4 & 57 & 1 & 20 \\
\hline erb-B2 B\&T(+) & 10 & 37 & 4 & 36 & 4 & 57 & 1 & 20 \\
\hline erb-B2 B /\&or T(+) & 22 & 81 & 10 & 91 & 7 & 100 & 4 & 80 \\
\hline
\end{tabular}

HR: hormone receptor; HR positive: ER and/or PR positive 


\section{Discussion}

We evaluate the potential of erb-B2 molecular marker in $\mathrm{BC}$ detection and analyzed the expression of erb-B2 mRNA in the peripheral blood of female BC patients and normal subjects by RT-PCR method. Although, the erb-B2 mRNA expression was observed in a number of normal subjects, the results of our study demonstrate that there was a significant difference between normal subjects and $\mathrm{BC}$ patients with the expression of erb-B2 molecular marker $(\mathrm{p}<0.01)$. erb-B2 molecular marker in peripheral blood was shown with low sensitivity $(44 \%)$ and good specificity (90\%), with only $12 \%$ false positive results in healthy controls, in our study. In our previous study, we found detected transcripts of erb-B2 in peripheral blood of 60 pretreated $\mathrm{BC}$ patients that was significantly different from 30 healthy controls $(\mathrm{p}<0.05)$ (Oloomi et al., 2013). In other study, plasma erb-B2 mRNA was shown in both peripheral blood of $\mathrm{BC}$ patients (43.3\%) and healthy females $(10 \%)$ (Xu et al., 2006). Other investigators have shown that erb-B2 mRNA-positive cells were not detected in the peripheral blood of healthy female controls (wasserman et al., 2000; Apostolaki et al., 2009). We have also studied the erb-B2 gene expression by RT-PCR method in fresh $\mathrm{BC}$ tissue samples and found that there was a significant difference between the expression of erb-B2 in the peripheral blood and tissue samples of BC patients $(\mathrm{P}<0.001)$. On the other hand, the frequency of positive erb-B2 mRNA expression in peripheral blood samples was less than positive RT-PCR erb-B2 in tissue samples.

In this study, we also assessed the correlation of erb-B2 mRNA marker positivity in peripheral blood and tumor tissue samples with clinical and pathological factors in invasive ductal BC patients. Expression of erb-B2 in peripheral blood or in both peripheral blood and tumor tissue of 31 patients were directly correlated with lymphovascular invasion and perineural invasion as poor prognostic features. Additionally, our results also indicated that in these 31 patients lymphovascular invasion was correlated with lymph node (data was not shown). Previous studies reported that the presence of lymphovascular invasion was an important prognostic factor in patients with lymph node-negative and in patients with lymph node-positive breast cancer (de Mascarel et al., 1998; Song et al., 2011). Unlike lymphovascular invasion, Duraker et al showed that perineural invasion has no prognostic value in IDC patients (Duraker et al., 2006). This study showed no correlation between erb-B2 mRNA expression in peripheral blood and/or tumor tissue and other prognosis factors. In this study, there is not significant correlation between the expression of erb-B2 and tumor size or lymph node in BC patients as mentioned in previous studies (Tse et al., 2005; Youssef et al., 2013).

The prognostic value of hormone receptors (HRs) is limited, but due to the importance of potential clinical utility of HER-2 status and ER/PR receptor, the correlation of these biologic markers has to be considered (Cianfrocca and Goldstein, 2004). In our study, the presence of erb-B2 mRNA in the peripheral blood was not associated with HRs, Ki67, p53 and HER-2 status. Positive immunohistochemical blood samples (18\%) and tissue samples $(0.04 \%)$ were detected that was not identified by RT-PCR. This discrepancy between RTPCR and immunohistochemical results can be justified by transcriptional or post-transcriptional activation. PCR false negative result was also shown between quantitative PCR and immunohistochemical methods (Königshoff et al., 2003; Tse et al., 2005). In the other hand, immunohistochemical negative blood sample (26\%) and immunohistochemical negative tissue sample (48\%) was identified by RT-PCR, in our study. False positive results using RT-PCR assays can be justify by the possibility of illegitimate transcription processes or the detection of specific transcripts in nonspecific cells (Pittman et al., 1996; Jung et al., 1997).

This is important that $20 \mathrm{BC}$ patients in stage I through stage IIIA had erb-B2-mRNA-positive CTCs in blood, 12 patients of these patients had HER-2-negative primary tumors. In other study, involving early breast cancer patients has shown that the presence of circulating tumor cells (CTCs) is associated with a worse prognosis (Graves and Czerniecki, 2011). Moreover, erb-B2-positive CTCs do not necessarily imply the positive-HER-2 status of the primary tumor (Cao et al., 2010).

Because of gene-expression-based subtype classification systems (Zhao et al., 2015) and various therapeutic responses or disease outcome that can be affected by means of different types of tumors (Yan et al., 2015), in the present study, $50 \mathrm{BC}$ patients were divided into 4 groups: A (ER and/or PR positive and HER-2 negative), B (HR positive and HER-2 positive), C (HR negative and HER-2 positive) and D (HR negative and HER-2 negative) according to hormone receptor and HER2 status. We compared the erb-B2 expression in peripheral blood and tumor tissue between different groups. In these cases, the highest rate of erb-B2 expression in peripheral blood or tumor tissue was in HER-2 positive group. It is worth mentioning that, HER-2 positive breast cancers tend to be aggressive and fast-growing, and traditionally associated with a poor prognosis.

In conclusion, positive erb-B2 expression in peripheral blood and tumor tissue samples was higher in HR negative/ HER-2 positive group of molecular breast cancer subtypes. In the other hand, positive erb-B2 expression was higher in blood and/or tumor tissue samples of malignant IDC patients than healthy control females. Additionally, erb-B2 expression in peripheral blood or in both peripheral blood and tumor tissue of BC patients correlates with lymphovascular and perineural invasion. This study suggests that the application of the RT-PCR and immunohistochemical methods for erb-B2/HER-2 molecular marker would provide a higher detection rate especially in stage early stages of breast cancer.

\section{Acknowledgements}

The authors wish to thank all patients who participated in the study. Besides, it is necessary to thank Dr. Maria Hashemian in specimen collection from Milad hospital. 


\section{References}

Apostolaki S, Perraki M, Kallergi G, et al (2009). Detection of occult HER2 mRNA-positive tumor cells in the peripheral blood of patients with operable breast cancer: evaluation of their prognostic relevance. Breast Cancer Res Treat, 117, 525-34.

Balleine RL, Wilcken NR (2012). High-risk estrogen-receptorpositive breast cancer: identification and implications for therapy. Mol Diagn Ther, 16, 235-40.

Cao S, Li Y, Li J, et al (2010). Quantitative determination of HER2 expression by confocal microscopy assay in CTCs of breast cancer. Oncol Rep, 23, 423-8.

Cianfrocca M, Goldstein LJ (2004). Prognostic and predictive factors in early-stage breast cancer. Oncologist, 9, 606-16.

de Mascarel I, Bonichon F, Durand M, et al (1998). Obvious peritumoral emboli: an elusive prognostic factor reappraised. Multivariate analysis of 1320 node-negative breast cancers. Eur J Cancer, 34, 58-65.

Dey S (2014). Preventing breast cancer in LMICs via screening and/or early detection: The real and the surreal. World J Clin Oncol, 5, 509-19.

Duraker N, Caynak ZC, Turkoz K (2006). Perineural invasion has no prognostic value in patients with invasive breast carcinoma. The Breast, 15, 629-34.

Gilbey AM, Burnett D, Coleman RE, Holen I (2004). The detection of circulating breast cancer cells in blood. Clin Pathol, 57, 903-11.

Graves H, Czerniecki BJ (2011). Circulating tumor cells in breast cancer patients: An evolving role in patient prognosis and disease progression. Pathology Research International, 621090.

Jung FA, Buzaid AC, Ross MI, et al (1997). Evaluation of tyrosinase mRNA as a tumor marker in the blood of melanoma patients. J Clin Oncol, 15, 2826-31.

Königshoff M, Wilhelm J, Bohle RM, et al (2003). HER-2/ neu Gene Copy Number Quantified by Real-Time PCR: Comparison of gene amplification, heterozygosity, and immunohistochemical status in breast cancer tissue. Clin Chem, 49, 219-229.

Oloomi M, Bouzari S, Mohagheghi MA, Khodayaran-Tehrani $\mathrm{H}$ (2013). Molecular markers in peripheral blood of Iranian women with breast cancer. Cancer Microenviron, 6, 109-16.

Owrangi B, Habibagahi M, Hosseini A, et al (2013). MDM2, E-cadherin, Survivin and Her2 mRNA status in peripheral blood of patients with breast cancer. Middle East Journal of Cancer, 4, 7-14.

Pittman K, Burchill S, Smith B, et al (1996). Reverse transcriptase polymerase chain reaction for expression of tyrosinase to identify malignant melanoma cells in peripheral blood. Ann Oncol, 7, 297-301.

Ross JS, Slodkowska EA (2009). Circulating and disseminated tumor cells in the management of breast cancer. Am J Clin Pathol, 132, 237-45.

Song JY, Shin SH, Cho JS, et al (2011). The role of lymphovascular invasion as a prognostic factor in patients with lymph nodepositive operable invasive breast cancer. J Breast Cancer, 14, 198-203.

Taghavi A, Fazeli Z, Vahedi M, et al (2012). Increased trend of breast cancer mortality in Iran. Asian Pac J Cancer Prev, 13, 367-70.

Tse C, Brault D, Gligorov J, et al (2005). Evaluation of the quantitative analytical methods real-time PCR for HER-2 gene quantification and ELISA of serum HER-2 protein and comparison with Fluorescence in situ hybridization and immunohistochemistry for determining HER-2 Status in breast cancer patients. Clin Chem, 51, 1093-1101.
Wang WJ, Lei YY, Mei JH, Wang CL (2015). Recent progress in HER2 associated breast cancer. Asian Pac J Cancer Prev, 16, 2591-600.

Wasserman LM, Jones V, Easter D, et al (2000). RT-PCR detection of circulating breast cancer cells: sensitivity and specificity of HER2/neu as a marker. Cancer Deyction and Prevention, 24.

$\mathrm{Xu}$ Y, Yao L, Li H, et al (2006). Presence of erbB2 mRNA in the plasma of breast cancer patients is associated with circulating tumor cells and negative estrogen and progesterone receptor status. Breast Cancer Res Treat, 97, 49-55.

Yan J, Liu XL, Han LZ, et al (2015). Relation between Ki-67, ER, PR, Her2/neu, p21, EGFR, and TOP II- $\alpha$ Expression in Invasive Ductal Breast Cancer Patients and Correlations with Prognosis. Asian Pac J Cancer Prev, 16, 823-9.

Youssef MF, Sabbour GS, Yousef MSM, et al (2013). HER-2/ neu in human breast cancer by real time reverse transcriptase polymerase chain reaction and immunohistochemistry. Life Sci J, 10, 430-443.

Zhao X, Rødland EA, Tibshirani R, Plevritis S (2015). Molecular subtyping for clinically defined breast cancer subgroups. Breast Cancer Research, 17, 29-37. 